\title{
nature
}

16 December 2004 Volume 432 Issue no 7019

\section{Strength through diversity}

A plan to reform appropriations committees in the US Congress - and create one devoted to science - is unlikely to come to fruition. Which is just as well.

$\mathrm{T}$ he research and development programmes of the US federal government are scattered across departments and congressional committees in a rather haphazard way. For decades, tidy minds have suggested improvements. But these have been ignored - and US science has gone from strength to strength.

The latest proposal comes from Tom DeLay (Republican, Texas), the majority leader in the House of Representatives, who wants to streamline the appropriations subcommittees that set budgets. His plan reportedly includes a subcommittee for science that would take under its wing NASA, the National Institutes of Health (NIH), the National Science Foundation (NSF) and the research programmes in the Department of Energy (DOE).

At present, the science agencies are scattered across different appropriations subcommittees, so NASA competes directly with the veterans affairs and housing departments for money. The NIH competes with agencies such as the education department. This may lack logic, but it has served science well. The scientific agencies have each found champions in both houses of Congress who know what they do and support their work. The current system also means that the major science agencies don't compete directly with each other for money - decisions about how to fund space science are made separately from choices on biomedical research. The system has put a brake on the sudden diversion of money into spheres that are fashionable or politically correct, and has helped to build the strongest and most diverse research enterprise the world has ever seen.

Putting everything in the hands of a single appropriations subcommittee could unravel all that. Agencies would compete bitterly for funds and the wrong priorities might take hold. The dynamics of congressional committees would suggest that members with large NASA or DOE facilities in their districts would come to dominate the subcommittee, draining clout from agencies such as the NIH and the NSF, which give small grants to researchers all over the country.

Maybe that's part of what DeLay is seeking. He recently intervened to restore the NASA budget - partly in defence of President Bush's human spaceflight plans, and partly to flex some muscle on behalf of the Johnson Space Center in his own district. He may believe that a research subcommittee would better serve NASA's interests. But the broader intention of his plan, according to Capitol Hill newspaper Roll Call, which broke the news on 6 December, is to realign the budget system to help the Republican leadership to shrink the federal government.

But even the man known in Washington as 'The Hammer' will have his hands full reforming such an entrenched system. The House will be reluctant to break up its current structure, and the Senate is expected to be hostile. No one expects any action soon, but that could change if the Republicans strengthen their grip on the Senate in 2006.

This inertia is probably good news for science, and for science lobbyists, who complain about the current system but know how to work it. As one biomedical lobbyist said last week: "I would rather fight nine small battles for adequate funding for research than have one large budget battle, in which a gain for one area of science came at the expense of all the rest." Excessive concentration of power over distributing research funds would lead to more political interference, more funding instability, and less diversity in US research.

\section{Fishing's secretive controllers}

\section{Those who are publicly funded to regulate harvesting of the oceans should stop barring the public from their discussions.}

A s the international agency controlling fishing for 30 migratory Aspecies in the Atlantic Ocean, the International Commission for the Conservation of Atlantic Tunas (ICCAT) has a vital ecological role. From the spawning waters of the Gulf of Mexico, up across the feeding grounds of the North Atlantic and into stock-rich regions of the Mediterranean, ICCAT decisions on allowable commercial catches can have a huge environmental impact. They affect target species, such as bluefin tuna or swordfish, creatures ensnared as bycatch — notably sharks or dolphins — and their food webs.

Timely, proper assessments of the stocks of specific species, analysis of the age and size of captured fish, and understanding of the effect of years of overfishing should be integral components of ICCAT deliberations. These should lead to science-based management decisions on the economically important and culturally rich resources under the stewardship of the Madrid-based agency. They don't.

Disturbingly, the media and the public are blocked from observing ICCAT discussions. Only in recent years did ICCAT allow some non-governmental organizations to attend its conferences, but even they must pay an 'observer fee' of at least US\$500, a move clearly designed to limit access.
Officials at the US National Marine Fisheries estimate that US taxpayers contributed some $\$ 250,000$ to host ICCAT's meeting in New Orleans last month, which included representatives of 23 nonmember fishing nations. Deliberations - funded by the taxpayers of the respective nations - affect the international public's resources. Given this public funding, such meetings should be open, but, apart from a press conference at the start, reporters were barred.

What do ICCAT members have to hide? Shamefully, representatives of the major markets in Asia and the heaviest fishing nations in Europe choose to meet in private and put their economic interests ahead of science-based management. This is what happened in New Orleans (see Nature 432, 539; 2004).

One ICCAT delegate suggested that the reason the press was not allowed in was because this would disturb developing nations. Excuses like this show the lengths to which officials will go to keep proceedings under wraps.

Transparency is essential if we are to understand what is happening to ocean resources. The Convention on Biological Diversity operates in such a manner. ICCAT should follow its example, starting by opening up its next meeting in Japan in April. 